\title{
Manajemen Kesetiaan Istri yang Menjalani Long Distance Marriage pada Istri Pelaut
}

\author{
Lidya Nur Amana', Suryanto ${ }^{2,}$ Isrida Yul Arifiana ${ }^{3}$ \\ ${ }^{1}$ Program Studi Magister Sains Psikologi Universitas 17 Agustus 1945 Surabaya, ${ }^{2}$ \\ Fakultas Psikologi Universitas Airlangga Surabaya, ${ }^{3}$ Fakultas Psikologi Universitas 17 \\ Agustus 1945 Surabaya \\ Email: lidya_s2@untag-sby.ac.id
}

\begin{abstract}
Abstrak
Hubungan pernikahan jarak jauh, memiliki permasalahan tersendiri khususnya ketika pasangan tidak bisa saling bertemu ketika saling membutuhkan, tak dapat melakukan kontak fisik sesering yang diinginkan oleh tiap pasangan dalam pernikahan. Kondisi tersebut pada akhirnya dapat mempengaruhi kualitas hubungan dari pasangan, hingga akhirnya dapat mempengaruhi ketangguhan pasangan dalam menghadapi permasalahan rumah tangga. Manajemen kesetiaan merupakan upaya untuk mengabdikan keyakinan hati atau perasaan pada pasangan. Dalam teori segitiga cinta Stenberg, komitmen merupakan komponen dari cinta. Makna dari komitmen dalam teori cinta Stenberg adalah suatu keputusan yang diambil seseorang bahwa dia mencintai orang lain dan secara berkesinambungan akan tetap mempertahankan cinta tersebut. Tujuan penelitian ini yaitu mendeskripsikan manajemen kesetiaan yang ditunjukkan istri dalam long distance marriage. Penelitian ini merupakan jenis penelitian kualitatif. Subjek dalam penelitian ialah istri pelaut dengan kriteria usia perkawinan lebih dari 5 tahun dan pekerjaan suami berlayar di luar Indonesia. Teknik pengambilan data menggunakan teknik observasi dan wawancara informal. Berdasarkan hasil analisis data kualitatif, dapat disimpulkan bahwa manajemen kesetiaan istri dipengaruhi oleh faktor internal dan eksternal. Faktor internal meliputi, keyakinan, pemahaman akan kondisi suami, komitmen dan strategi coping yang dimiliki istri. Sedangkan, faktor eksternal meliputi dukungan suami, dukungan keluarga dan kualitas dalam menjaga hubungan ketika bertemu. Manajemen kesetiaan yang ditunjukkan dalam pernikahan jarak jauh (long distance marriage) mampu menumbuhkan ketangguhan pasangan dalam menjaga keharmonisan keluarga.
\end{abstract}

Kata Kunci : Manajemen Kesetiaan, Komitmen, Long Distance Marriage

\section{Pendahuluan}

Pada saat ini pernikahan menjadi sorotan penting dalam kehidupan masyarakat karena ikatan pernikahan sangat menentukan masa depan bangsa. Pernikahan yang gagal akan menimbulkan banyak dampak yang besar dalam 
PSISULA: Prosiding Berkala Psikologi

Vol. 1, 2019

E-ISSN: 2715-002X

kehidupan masyarakat. Pertama berdampak pada anak-anak, antara lain terjadi kenakalan remaja, bunuh diri, dan penyalagunaan narkoba. Kedua, meningkatkan angka kemiskinan karena pertimbangan dan perencanaan ekonomi yang minim (kurang) dalam rumah tangga. Ketiga, kualitas sumber daya manusia (SDM) yang lemah karena ketidakmampuan orang tua dalam mendidik dan mengasuh anak (Iqbal, 2018).

Pernikahan merupakan momen penting dan sakral bagi seluruh pasangan pria dan wanita. Tanpa adanya sebuah pernikahan tentu tidak akan tercipta sebuah keluarga dan tidak akan bisa melahirkan keturunan-keturunan baru. Pada umumnya, pernikahan diartikan sebagai suatu proses adanya ikatan janji suci yang dilakukan oleh individu-individu yang sudah matang secara psikologis. Menurut Hurlock (1980) pernikahan merupakan periode individu belajar hidup bersama sebagai suami istri membentuk suatu keluarga, membesarkan anak-anak, dan mengelola sebuah rumah tangga. Jika tugas ini dapat dilalui dan diselesaikan dengan baik, akan membawa kebaikan pada individu tersebut. Pasangan yang memutuskan untuk menikah pasti memiliki harapan dan tujuan yang ingin dicapainya. Selain untuk membentuk rumah tangga yang bahagia dan memperoleh keturunan, tujuan lainnya yaitu untuk menumbuhkan kesungguhan berusaha mencari rezeki penghidupan yang halal dan memperbesar rasa tanggung jawab (Harahap dalam Mardani, 2011).

Bekerja untuk mencari rezeki biasanya dilakukan oleh salah satu pasangan dan umumnya dikerjakan oleh suami sebagai kepala keluarga yang menafkahi istri dan anak-anaknya. Namun, tidak menutup kemungkinan bagi istri untuk bekerja membantu pendapatan suami agar kebutuhan rumah tangganya dapat terpenuhi. Setiap pasangan suami istri umumnya menginginkan untuk tinggal bersama di dalam satu rumah, namun ada beberapa keluarga yang tidak tinggal bersama di dalam satu rumah dikarenakan berbagai macam hal. Menjalani pernikahan jarak jauh ini tidaklah mudah terutama bagi wanita memiliki kebiasaan belum bisa mandiri dalam menjalani aktivitas sehari-hari. Skinner (2005) mengatakan bahwa komitmen dalam hubungan bervariasi menurut jenis kelamin. Beberapa studi 
PSISULA: Prosiding Berkala Psikologi

Vol. 1, 2019

E-ISSN: 2715-002X

menemukan bahwa wanita menunjukkan dan mengungkapkan komitmen dalam hubungan dari pada laki-laki. Ada suami istri yang tidak dapat mengatasi konflik dalam perkawinan, sehingga memutuskan untuk menempuh jalan perceraian (Dariyo, 2004).

Beberapa tahun belakangan ini, angka perceraian di Indonesia terus meningkat. Berdasarkan data dari Dirjen Badan Peradilan Agama, Mahkamah Agung (tahun 2016), pada periode 2014-2016, angka perceraian di Indonesia meningkat, yakni dari 344.237 perceraian pada tahun 2014 lalu naik menjadi 365.633 perceraian pada tahun 2016 (Iqbal, 2018). Fenomena ini merupakan fakta yang tidak bisa dihindari. Ada banyak faktoir yang menjadi penyebab terjadinya perceraian, mulai dari persoalan ekonomi, kekerasan dalam rumah tangga, konflik keluarga, perselingkuhan, penggunaan narkoba, tidak melaksanakan ibadah agama, dan lain-lain. Perselingkuhan kerap terjadi pada kondisi pasangan yang menjalani hubungan pernikahan jarak jauh, biasanya pasangan akan mengalami krisis dalam kedekatannya yang disebabkan oleh jarak. Keintiman atau kedekatan yang dijaga melalui alat komunikasi juga dapat menimbulkan kemungkinan adanya pertengkaran, pertengkaran bisa timbul karena adanya perbedaan pemahaman selama komunikasi berlangsung. Pernikahan jarak jauh erat kaitannya dengan cinta. Sebagaimana dikemukakan oleh Stenberg (1986) dalam teorinya tentang segitiga cinta (The Triangular Theory of Love).

Menurut Stenberg, cinta didefinisikan bentuk emosi manusia yang paling dalam dan paling diharapkan. Manusia mungkin akan berbohong, menipu, mencuri dan bahkan membunuh atas nama cinta dan lebih baik mati dari pada kehilangan cinta. Cinta dapat meliputi setiap orang dan dari berbagai tingkatan usia. Dalam teori segitiga cinta Stenberg disebutkan bahwa cinta memiliki tiga komponen utama. Pertama, gairah (Passion) merupakan dorongan yang mengarahkan pada suatu emosi yang kuat dalam hubungan cinta tersebut. Dalam hubungan cinta romantis, ketertarikan fisik dan seksual mungkin adalah hal yang utama. Namun motif yang lainnya seperti memberi dan menerima perhatian, kebutuhan akan harga diri atau kebutuhan untuk mendominasi mungkin turut terlibat. Kedua, 
PSISULA: Prosiding Berkala Psikologi

Vol. 1, 2019

E-ISSN: 2715-002X

keintiman merupakan perasaan ingin selalu dekat, ingin selalu berhubungan, membentuk ikatan dengan orang yang dicintai. Dalam komponen ini, ada keinginan untuk selalu memberi perhatian pada orang yang dicintai. Ketiga, komitmen (commitment) merupakan suatu keputusan yang diambil seseorang bahwa dirinya mencintai orang lain dan secara berkesinambungan akan tetap mempertahankan cinta tersebut. Hal ini adalah komponen kognitif utama dari cinta. Komponen komitmen sendiri mempunyai dua aspek jangka pendek dan jangka panjang. Aspek jangka pendek adalah keputusan untuk mencintai seseorang. Sedangkan keputusan jangka panjang adalah untuk mempertahankan hubungan cinta tersebut. Kedua aspek ini tidak harus dialami bersama-sama.

Keputusan untuk mencintai belum tentu mengakibatkan munculnya keinginan untuk mempertahankan hubungan. Kesetiaan merupakan bagian dari komitmen, komitmen yang kuat dalam diri seorang istri akan mendatangkan kebahagiaan yang membuat istri memiliki kekuatan untuk menghadapi tantangan yang dialami selama jauh dengan suaminya. Merasakan bahagia ditunjukkan dengan segala bentuk rasa syukur dan keikhlasan dalam menjalankan amanah yang diberikan suami kepada istri. Seorang istri yang jauh dari suami diberikan amanah yang lebih untuk menjaga keutuhan rumah tangga dan membesarkan serta mendidik anak tanpa didampingi oleh suami setiap waktu. Cinta mendorong pecinta untuk melakukan aktivitas yang terpuji, seperti keberanian, kedermawanan, pengorbanan, dan sebagainya. Cinta melibatkan gerak yang positif yang menimbulkan perasaan yang bahagia (Shihab, 2011).

Berdasarkan dari fenomena diatas serta penelitian yang telah dilakukan sebelumnya, maka peneliti tertarik ingin melakukan penelitian dengan judul “Management Kesetiaan pada istri yang menjalani pernikahan jarak jauh (Long distance marriage)".

\section{Metode Penelitian}

Desain penelitian, penelitian ini menggunakan pendekatan kualitatif. Penelitian ini menggunakan pendekatan kualitatif. Penelitian kualitatif adalah 
PSISULA: Prosiding Berkala Psikologi

Vol. 1, 2019

E-ISSN: 2715-002X

penelitian yang menekankan pada quality atau hal yang terpenting dari sifat suatu barang/jasa. Menurut Bogdan \& Bilklen (dalam Rahmad, 2009) adalah salah satu prosedur penelitian yang menghasilkan data deskriptif berupa ucapan atau tulisan dan perilaku orang-orang yang diamati. Penelitian kualitatif ini mengarah pada pendekatan fenomenologi dengan menggunakan metode wawancara. Penelitian kualitatif ini mengarah pada pendekatan fenomenologi dengan menggunakan metode wawancara.

Partisipan, penentuan informan penelitian dalam penelitian ini menggunakan teknik purposive yaitu informan penelitian dipilih berdasarkan pertimbangan, kriteria atau ciri-ciri yang ditetapkan berdasarkan tujuan penelitian. Adapun informan dalam penelitian ini memiliki kriteria diantaranya, istri yang tinggal berbeda negara dengan suami, usia perkawinan minimal 5 tahun.

Prosedur, prosedur penelitian yang dilakukan oleh peneliti adalah didasarkan pada tahapan dalam proses penelitian kualitatif oleh Neuman (2017) yaitu : menentukan pertanyaan untuk penelitian, merancang desain penelitian, mengumpulkan data, menganalisis data, menginterpretasi data, membuat laporan penelitian. Metode pengumpulan data menggunakan wawancara semi terstruktur terdiri dari beberapa pertanyaan terbuka kemudian memulai dengan pertanyaan umum dan beralih ke pertanyaan pribadi ketika sudah menjalin rapport. Setelah dilakukan wawancara, peneliti melakukan proses transkrip hasil wawancara. Proses transkrip wawancara yaitu detailed transcription yaitu peneliti menuliskan kataperkata yang diucapkan oleh partisipan.

Teknik analisa data, Analisa data adalah proses mencari dan menyusun secara sistematis data yang diperoleh dari hasil wawancara, catatan lapangan, dan dokumentasi dengan cara mengorganisasikan data ke dalam kategori, menjabarkan ke dalam unit-unit, melakukan sintesa, menyusun ke dalam pola, memilih mana yang penting dan yang akan dipelajari, serta membuat kesimpulan sehingga mudah dipahami oleh diri sendiri dan orang lain. Model analisa data dalam penelitian ini mengikuti konsep yang diberikan Miles dan Huberman. Miles dan Huberman (1984) mengungkapkan bahwa aktivutas dalam analisis data kualitatif dilakukan secara 
PSISULA: Prosiding Berkala Psikologi

Vol. 1, 2019

E-ISSN: 2715-002X

interaktif dan berlangsung secara terus menerus pada setiap tahapan penelitian sehingga sampai tuntas.

\section{Hasil Penelitian dan Diskusi}

Berikut ini adalah tabel yang merangkum keseluruhan hasil penelitian dengan pendekatan Fenomenologi.

Tabel 1. Tabel Tema Induk dan Tema Sub Ordinat

\begin{tabular}{ll}
\hline 1. Keintiman & $\begin{array}{l}\text { 1. Mempertahankan rasa cinta } \\
\text { 2. Memberikan dukungan }\end{array}$ \\
\hline 2. Gairah & $\begin{array}{l}\text { 1. Pemenuhan kebutuhan biologis pada pasangan } \\
\text { LDM }\end{array}$ \\
\hline 3. Komitmen & $\begin{array}{l}\text { 1. Pentingnya komunikasi dalam pernikahan } \\
\text { 2. Masalah dalam pernikahan }\end{array}$ \\
& 3. Menjalani dan mempertahankan komitmen
\end{tabular}

\section{Keintiman}

Peneliti mencoba untuk menjelaskan kondisi tiap subjek mengenai bagaimana menjaga keintiman pada istri yang menjalani long distance marriage pada istri pelaut. Pada subjek pertama ibu SJ untuk menjaga keintiman pada suaminya yaitu menjaga rasa cinta dengan mendoakan suminya, lancar dalam bekerja, baik-baik saja dan berdoa agar suami dijauhkan dari pengaruh negatif, karena banyak rekan kerja suami yang melakukan perselingkuhan, hal tersebut diketahui ibu SJ, ketika suami dari ibu menceritakan kehidupan dikapal. Ibu SJ dan suami selalu mendukung kegiatan satu sama lain, selain menjadi ibu rumah tangga, ibu SJ juga memiliki kerjaan sampingan yaitu berjualan makanan ringan. Bentuk dukungan yang diberikan suami pada ibu SJ adalah memberikannya modal untuk membuka usaha, memberikan semangat pada ibu SJ, begitupun sebaliknya, ibu SJ selalu memberikan semangat kepada suami, terlebih juga pekerjaan suami di kapal sangatlah berat. 
PSISULA: Prosiding Berkala Psikologi

Vol. 1, 2019

E-ISSN: 2715-002X

Pada subjek kedua ibu EF menjaga keintiman pada suaminya yaitu menjaga rasa cinta dengan cara menyakini dan percaya kepada suami jika suaminya juga mencintainya dan tidak akan menghianati dirinya, pikiran selalu dibuat positif tentang suami disana, selalu ingat bahwa suami bekerja untuk membahagiakan dirinya dan putri semata wayangnya dengan bertaruh nyawah melewati badai dan gelombang. Ibu EF sangat mendukung pekerjaan yang dilakukan suaminya saat ini, meskipun merasa sedih harus mejalani pernikahan LDM ini, untuk mengurangi kesedihannya, ibu EF selalu percaya bahwa apa yang dijalani saat ini adalah bentuk takdir dari Tuhan untuknya dan mau tidak mau harus dia jalani dengan ikhlas. Selain menjadi ibu rumah tangga ibu EF ini juga menjadi penulis buku “ 2823 Miles Apart” buku itu merupakan cerita perjalanan ibu EF dengan suaminya selama mejalani pernikahan LDM, suami ibu EF mendukung karir ibu EF dan memberikan ijin bahwa cerita kehidupan rumah tangganya dibaca oleh masyarakat.

Subjek ke tiga ibu $M$ menjaga rasa cinta dengan selalu berfikir positif terhadap suami yang disana, selalu mendoakan suami dan melakukan hal yang menyenangkan, jika pada saat ibu $M$ merasa kesepian. Ibu $M$ dan suaminya saling mendukung karir masing-masing, dengan banyaknya pekerjaan yang dilakukan ibu $M$, ibu $M$ tidak pernah lupa memberikan semangat dan motivasi kepada suaminya, begitupun sebaliknya.

\section{Gairah}

Merupakan dorongan yang mengarahkan pada suatu emosi yang kuat dalam hubungan cinta tersebut. Dalam hubungan cinta romantis, ketertarikan fisik dan seksual mungkin adalah hal yang utama. Peneliti mencoba untuk menjelaskan kondisi tiap subjek mengenai bagaimana subjek memenuhi kebutuhan biologinya selama suami bekerja. Pada subjek pertama ibu SJ, diketahui bahwa :

"Setiap orang pasti membutuhkan hubungan kontak fisik dengan suaminya, namun karena keterbatasan waktu dan tempat yang saya alami dengan suami, maka kebutuhan biologis tersebut kurang terpenuhi, kami berdua sangat memahami hal itu, untuk memenuhi kebutuhan itu ya saya

Dipresentasikan dalam Seminar Nasional "Membangun Resiliensi di Era Revolusi Industri 4.0" Fakultas Psikologi Unissula, 22 September 2019 
PSISULA: Prosiding Berkala Psikologi

Vol. 1, 2019

E-ISSN: 2715-002X

menunggu suami saya pulang, saya juga selalu mengutarakan apa yang saya alami pada pada suami ketika hasrat akan kebutuhan itu muncul"

Pada subjek kedua ibu EF untuk memenuhi kebutuhan biologisnya sama dengan ibu SJ, yaitu menunggu suami pulang, ibu EF juga merasa bahwa hal tersebut tidaklah mudah bagi dirinya dan suami, namun apalagi yang bisa dilakukan selain bersabar satu sama lain, jika hasrat itu muncul bu EF selalu mengalihkan perasaan tersebut dengan bermain bersama anaknya, melakukan hal yang menyenangkan bersama anak dan keluarganya seperti jalan-jalan berlibur, itu merupakan bentuk upaya ibu EF meminimalisir hasrat kebutuhan biologisnya.

Pada subjek ketiga ibu $M$ untuk memenuhi kebutuhan biologisnya sama seperti ibu SJ, EF yaitu menunggu suami pulang, karena ibu $M$ adalah seorang perawat dan setiap harinya ibu $\mathrm{M}$ menghabiskan waktu di rumah sakit dan ketika pulang menghabiskan waktu bersama anaknya, seperti membantu anak mengerjakan PR dan hal tersebut yang dirasa Ibu M dapat mengalihkan hasrat kebutuhan biologisnya tersebut. Begitu banyak tenaga dan pikiran yang dikeluarkan saat bekerja, sehingga hasrat tersebut cenderung tidak muncul.

Hasil penelitian mengatakan bahwa untuk memenuhi kebutuhan biologis 3 orang subjek memilih untuk menunggu suami dirumah. Hal ini sesuai dengan Lestari (2012) kualitas relasi seksual merupakan kekuatan penting bagi kebahagiaan pasangan, maka kualitas tersebut perlu dijaga dan ditingkatkan melalui komunikasi seksual antar pasangan. Komunikasi seksualitas akan membantu pasangan untuk saling memahami perspektif masing-masing terhadap kebutuhan dan ketertarikan seksual.

\section{Komitmen}

Pada subjek pertama ibu SJ untuk mempertahankan pernikahan selama menjalani pernikahan jarak jauh dengan suami adalah dengan selalu menjaga komunikasi dengan suami, tetap memberi kabar kepada suami meskipun tidak ada signal, jadi ketika ada signal pesan dari istri otomatis langsung terkirim, menjaga etika ketika berteman dengan lawan jenis, menghindari petemuan acara yang 
PSISULA: Prosiding Berkala Psikologi

Vol. 1, 2019

E-ISSN: 2715-002X

memungkinkan terjadinya perselingkuhan, seperti reuni sekolah SMP atau SMA, karena sekarang banyak perselingkuhan terjadi berawal dari mengikuti acara reuni.

Pada subjek kedua ibu EF untuk mejaga komunikasinya hampir sama dengan subjek 1 yaitu ibu SJ, ibu EF juga akan selalu menghubungi suaminya jika ada sinyal, menggunakan gadget sebaik mungkin, tidak menimbulkan prespektif kepada masyarakat bahwa istri yang menjalani long distance marriage kesepian, membutuhkan perhatian dan kasih sayang, sehingga tidak memberikan kesempatan pada laki-laki lain untuk mendekat. Melakukan hobi ketika tidak ada kerjaan dan saat rasa rindu pada suami sangat besar, hobi sebagai pengalihan rasa rindu kepada suami, setidaknya rasa rindu yang menumpuk tidak menimbulkan kesedihan ketika suami tidak bisa di hubungi. Subjek ketiga ibu M juga sama dengan ibu SJ dan EF, selalu menjalin komunikasi dengan baik kepada suami, selalu menceritakan keseharian yang dialami bersama anak-anaknya, sehingga hal tersebut dapat membuat suaminya tenang dan tidak terlalu khawatir terhadap keadaan istri dan anaknya. Subjek tidak menghiraukan perkataan orang lain yang mengatakan, bahwa pelaut itu suka main perempuan dan hidupnya bebas, ibu $M$ sangat percaya suaminya disana juga menjaga cinta untuk istri dan anaknya. Ibu $M$ juga menyatakan :

"Menjalani pernikahan jarak jauh memang tidaklah mudah, belum lagi ketika ada masalah dalam keluarga, masalah anak, dimana kita sebagai seorang istri yang jauh dari suami harus bisa mengatasi masalah tersebut sendiri, tidak semua permasalahan harus diceritakan pada suami, karena saya paham kerjaan suami saya di kapal sangatlah berat, jadi ketika saya mengalami suatu masalah, saya akan cari dulu solusinya sendiri, jika saya membutuhkan pertimbangan dalam menyelesaikan permasalahan maka akan saya sampaikan kepada suami, tetapi melihat kondisi suami saya, apakah suami saya siap mendengarkan masalah yang saya hadapi, apakah suami saya dalam kondisi yang fit dan tidak kelelahan dalam bekerja"

Komitmen dalam pernikahan juga berkaitan dengan keharmonisan dan keintiman. Komitmen atau keputusan yang diambil dalam menjalani hubungan pernikahan jarak jauh merupakan keputusan bersama dengan pasangan. Pada ketiga subjek penelitian, komitmen yang dijalani ketiganya adalah menerima 
PSISULA: Prosiding Berkala Psikologi

Vol. 1, 2019

E-ISSN: 2715-002X

dengan kondisi hubungan pernikahan jarak jauh. Menurut (Johnson, 1999), terdapat tiga komitmen yang menjadi sumber motivasi untuk mengatasi masalah, dengan motivasi tersebut dapat tercipta perencanaan dan tindakan untuk menyelesaikan masalah dalam hubungan pernikahan tersebut.

\section{Kesimpulan}

Berdasarkan pekerjaan yang dijalani, subjek yang memiliki pekerjaan cenderung menghabiskan waktu dengan bekerja dan mendoakan suami. Pada subjek yang tidak memiliki pekerjaan cenderung menghubungi suami, menghabiskan waktu dengan anak, keluarga dan teman. Berdasarkan jarak yang ditempuh, pada jarak yang tergolong jauh (Eropa, dan Singapura) dalam menyelesaikan masalah subjek cenderung menyatukan pendapat dari suami maupun istri, apabila ada masalah yang sama salah satu harus merubah sikap, dan memberikan waktu untuk berpikir. Faktor yang mempengaruhi cinta pada istri yang menjalani pernikahan jarak jauh dibagi menjadi dua, yaitu faktor internal dan faktor eksternal. Faktor internal yang mempengaruhi cinta pada istri yang menjalani pernikahan jarak jauh adalah keyakinan, komunikasi, pengertian, dan koping (kemampuan menyelesaikan masalah). Faktor eksternal yang mempengaruhi cinta pada istri yang menjalani pernikahan jarak jauh adalah jarak, dukungan suami, dan telepon. Cara untuk mempertahankan pernikahan jarak jauh adalah berkomunikasi satu sama lain, saling memberikan kepercayaan dan saling memahami satu lain.

Berdasarkan hasil penelitian yang dilakukan, maka peneliti mengajukan saran sebagai berikut :

1. Bagi istri yang menjalani pernikahan jarak jauh

Istri yang menjalani pernikahan jarak jauh diharapkan memiliki aktivitas yang produktif, sehingga tidak terlalu merasa khawatir dan berpikiran buruk terhadap suami ketika tidak memberi kabar. Saat merasa kesepian atau rindu dengan pasangan, dapat mengalihkan melalui kegiatan olahraga, memasak, bermain dengan anak atau aktivitas positif lainnya, sehingga tidak terpaku harus menghubungi pasangan jika pasangan sedang sibuk. Dan apabila ada 
PSISULA: Prosiding Berkala Psikologi

Vol. 1, 2019

E-ISSN: 2715-002X

permasalahan dalam rumah tangga sebaiknya dibicarakan, didiskusikan dan mencari jalan keluar secara bersama-sama dengan saling mengutarakan perasaan dan harapan pasangan suami istri

2. Bagi peneliti selanjutnya

Menggali lebih dalam tentang manajemen kesetiaan suami yang menjalani pernikahan jarak jauh dan upaya-upaya untuk mempertahankan pernikahan jarak jauh.

\section{Daftar Pustaka}

Dariyo, A. (2004). Memahami Psikologi Perceraian dalam Kehidupan Keluarga. Jurnal Psikologi, 2(2), 11-20.

Handayani, Yulastri. (2016). Komitmen, Confict Resolution, dan Kepuasan Perkawinan pada Istri yang Menjalani Hubungan Pernikahan Jarak Jauh (Karyawan Schlumberger Balikpapan). Psikoborneo, 4(6) 518-529.

Hatfield, E., \& Rapson, R. (2005). Love and sex: Cross-cultural perspectives. Needham Heights MA: Allyn \& Bacon.

Iqbal. M. ( 2018 ). Psikologi Pernikahan. Yogyakarta: Gema Insani Press

Johnson, M. (1999). The tripartite nature of marital commitment: Personal, moral, and structural reasons to stay married. Jounal of Marriage and The Family, 61(1), 160-171.

Lestari, S. (2012). Psikologi Keluarga (Penanaman Nilai \& Penanganan Konflik dalam Keluarga). Surakarta: Prenada Media Group

Lemieux, R. \&. (2002). Cross-sectional Analysis of Intimacy, Passion, and Commitment: Testing the Assumptions of The Triangular Theory of Love. Psychological Reports, 90(3); 1009-1014.

Mijilputri, N. (2015). Peran Dukungan Sosial terhadap Kesepian Istri yang menjalani Hubungan Pernikahan Jarak Jauh (Long Distance Marriage). eJournal Psikologi , 3(2) : 478.

Mendatu, A. (2010). Cinta Manusia : Arti, Ragam jenis, \& Sebab akibatnya. Psikoeduka, 28-30. 
PSISULA: Prosiding Berkala Psikologi

Vol. 1, 2019

E-ISSN: 2715-002X

Milles, M.B. and Huberman, M.A. 1984. Qualitative Data Analysis. London: Sage Publication

Neuman, W.L. (2006). Social research methods: qualitative and quantitative approaches. New York: Pearson Education.

Santrock, J. (2012). Life-Span Development :Perkembangan Masa Hidup Jilid Satu (edisi Ketigabelas) . Jakarta: Erlangga.

Skinner, B. (2005). Perceptions of College Students in Long Distance Relationship. Journal of Undergraduate Research VIII, 2.

Sternberg, R. J. (1986). A triangular theory of love. Intimacy, Passion, Commitment. Basic Books Inc.: New York 